\title{
Development of a National Rating System to Evaluate the Brand Attraction of Sewing and Knitting Enterprises
}

\author{
Alisher Rasuljanovich Oqboyev ${ }^{1}$; Moxigul Isroiljanovna Raximova²; Muxammadali Abdullajon \\ Ugli Qaxramonov ${ }^{3}$
}

${ }^{1}$ Doctor of Philosophy in Economics (PhD), Namangan Institute of Engineering and Technology, Namangan City, Uzbekistan

${ }^{2}$ Master Student, Department of "Management", Namangan Institute of Engineering and Technology, Namangan City, Uzbekistan

${ }^{3}$ Master Student, Department of "Metrology, Standardization and Quality Management (Textile and Light Industry)", Namangan Institute of Engineering and Technology, Namangan City, Uzbekistan

http://dx.doi.org/10.18415/ijmmu.v8i10.3142

\begin{abstract}
The article proposes a mechanism for creating a national rating system aimed at including local brands in the international ranking of global brands in order to assess the brand attractiveness of sewing and knitting companies operating in Uzbekistan. It recommends the methodology of rating of national and global brands, the main segments of the analysis of national brands, the direction of development of the rating system, the rating criteria for the evaluation of local brands and the sources of their identification. The development of a national rating system for brand evaluation will lead to the formation of a healthy competitive environment for local brands, protection of consumers from substandard products, the creation of an integrated system between enterprises and consumers.
\end{abstract}

Keywords: National Rating System; Brand Attraction; Sewing and Knitting Enterprises

\section{Introduction}

The development of science and innovation is crucial to ensure reliable protection of intellectual property while transforming advances in this field into high value-added products. The brand value of goods in the world is high. Intellectual property accounts for 45 percent of GDP in Europe, 12 percent in China, and 7 percent in Russia. The brand value of goods in the world is high. Today, 72 brands are internationally registered in the industry of our country. At a meeting of the President of the Republic of Uzbekistan Sh.M.Mirziyoev on October 12, 2020 on measures to improve the system of protection of intellectual property, "... The voice of Uzbekistan should be heard in our products, and only if there is a brand, our products will be able to take a strong place in foreign markets. If we can strengthen the protection of intellectual property, it will be a reliable foundation for the Third Renaissance."[1]

In particular, the Decree of the President of the Republic of Uzbekistan dated December 14, 2017 PF-5285 "On measures to accelerate the development of the textile and clothing industry" The seventh 
priority of the industry development is the introduction of advanced innovative technologies, know-how, design developments, localization of production of modern models of fittings and accessories.[2]

Today, not only Uzbek garment and knitting enterprises, but also enterprises in many countries around the world face the problem of increasing competition with imported products. The chosen policy of openness of the economy in Uzbekistan leads to the emergence of many international companies with strong and well-known brands in the market and a sharp change in the competitive environment. Such competitors offer high quality and cheap goods, the presence of a well-known brand is an important factor in ensuring the stability of the enterprise in the market, determining its competitiveness.

\section{Literature Review}

The scientific and theoretical aspects of the use of branding strategy in the management of the competitiveness of garment enterprises are reflected in the scientific developments of many foreign scientists. The scientific works of D.A.Aaker [2], J.Baker, D.Grewal [4], V.Badrinarayanan [5] and others have become classics in this regard. Despite the significant contribution of these long-term foreign scientists in the study of scientific and methodological aspects of brand management, strategic brand management and development of branding strategies in enterprises, the use of branding strategy in managing the competitiveness of garment enterprises has not been fully explored. Among the economists of the Republic MA Ikramov, Sh.Dj.Ergashkhodjaeva [6], Z.D.Adylova, D.S.Kasimova [7] and A.Okbaev, S.Eshmatov [812] researches on brand management in the republic have made and made a worthy contribution to the development of this field.

Brand Finance Nation Brands is a ranking of national and international brands established by the British international consulting company Brand Finance. Manufactured by a brand specializing in auditing and evaluation.[13]

The authors of the study believe that the status and reputation of a country's brand affects the development of the economy and its perception of its present and future, and this has a direct impact on the country's well-being and its ability to compete and develop globally. Although the methodology for rating global brands is based on many approaches in international practice, it is appropriate to cite the Royalty Relief Method as the main one. In this method, if a company (or country) uses a brand under a license agreement, it is based on a methodological approach that requires the licensee to pay a certain percentage royalties. Since the commodity being valued is the property of the company (country), the royalty is capitalized by the company (country) itself.

In calculating the rating of national brands, their brand value, stability and potential of product development, economic, demographic and political factors, including investment indicators, tourism attractiveness, economic growth dynamics of the studied countries, production, consumption and exports, national goods and services, human capital and other parameters are combined into four main segments.

Table 1. Key segments of national brand analysis

\begin{tabular}{|c|c|c|}
\hline Segment & Internal factors & External factors \\
\hline Investment & Domestic investment & Foreign investment \\
\hline Tourism & Domestic tourism & Foreign tourism \\
\hline Product & Domestic consumption of national goods and services & Export of domestic goods and service \\
\hline \multirow{2}{*}{ Human capital } & Domestic investment in human capital & Foreign investment in human capital \\
\hline
\end{tabular}


The Brand Finance Agency uses the results of national statistics and research conducted regularly by international institutions in the process of brand analysis of countries. It cooperates with international research organizations - the Institute of Management Development and the World Economic Forum. Based on comparative studies, each country is rated from AAA (strong national brand) to DDD (no national brand). These letter categories make up the brand index.

A detailed description of the national brand ranking formation methodology is provided in the annual reports of Brand Finance on the results of comparative research, as well as on the project website.

The development of a national rating system in order to include national brands in the international ranking as a global brand is a topical issue, and clear methodological guidelines for the preparation of local brands for the global market also provide an opportunity to set strategic directions. On this basis, it is important to develop and implement a national rating system for local brands of garment enterprises.

\section{Analysis and Results}

According to the strategic goals for the development of the textile industry until 2030, set by the "Uztuqimachilik" Association of Textile Industry, the volume of production of textiles, garments and knitwear in relation to cotton fiber amounted to 19.4 billion soums. It is planned to exceed the US dollar and more than 80 percent of it will be exported. This goal can be achieved by creating a global value chain. The development of strategies aimed at the formation of branding strategies in the textile cluster of Uzbekistan and the formation of scientific and methodological approaches are important in ensuring competitive advantage. In carrying out this task, an effective mechanism should be formed to increase the international prestige of national brands. Its main task is to develop scientific-methodological and practical recommendations, strategies, increase the global prestige of textile brands and create a global value chain.

Although the strategic objectives of enterprises operating in Uzbekistan for the formation of national brands have been developed, there are no comprehensive programs aimed at enhancing their international prestige. Identifying financial resources and opportunities to use them to enhance the international prestige of national brands will determine the main level of complexity of the project. It can be difficult to form partnerships with companies that are working on programs to increase the international prestige of national brands.

Evaluation and rating of brands of garments not only provides an effective competitive environment, but also creates a perfect system that protects producers and consumers in the local market. It will promote the formation of strong brands in Uzbekistan. The project will create a healthy competitive environment for national brands, protect consumers from substandard products, and create an integrated system between enterprises and consumers.

In the process of forming national brands, the user assists in the formation of scientific resources that define the methodological framework and target areas.

\section{Discussion of Results}

The organizational mechanism for developing a national rating system to include national brands in international rankings as a global brand is based on assessing brand strength based on indicators such as consumer satisfaction with the brand, quality, design, royalties, value creation and profitability. (Figure 1). 


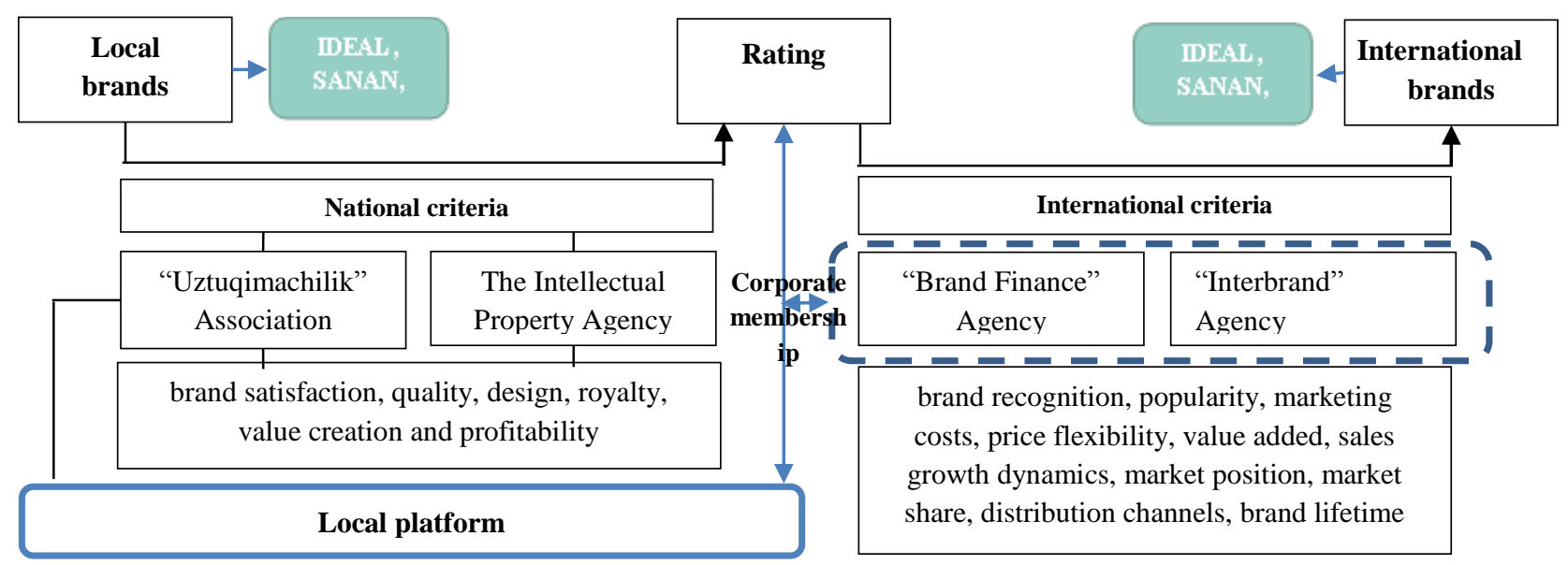

Figure 1. The mechanism of creating a national rating system aimed at the inclusion of local brands in the international ranking as a global brand

In order to ensure consumer convenience in the evaluation of brands on the basis of a rating system requires the formation of a separate Internet platform by the Association "Uztuqimachilik" Association. Special survey forms will be developed for brands that are members of this platform. This platform is also required to be "open" to consumers. This platform conducts research on strategic brand management of enterprises, studies consumers, analyzes results and helps to form effective branding for enterprises. In order to include national brands in the international ranking of global brands, the development of a national rating system provides for two main directions:

- Creation of a global value chain of the industry on the basis of formed sewing and knitting brands;

- Participation in the global value chain based on garment brands.

According to the proposed methodological approach, the rating of garment and knitwear enterprises on the basis of brand strength should be implemented from the point of view of consumers. The main reason for this is that brand value is formed in the consumer. This methodology requires the development of the minimum approaches and methods required for evaluation. It should be possible to use other approaches and methods of evaluation based on the rating system.

To assess the brand strength of garment enterprises, enterprises must be identified. The main condition is the existence of the right of ownership of the brand and the availability (patenting) of documents confirming its legal ownership. The following documents should also be accepted as a basis:

Availability of patents and certificates of the brand;

Copyright license agreements and other legal documents.

One of the most common methods of evaluation is evaluation based on this rating system. In order to ensure the convenience of consumer evaluation of brands on the basis of a rating system, the Association "Uztuqimachilik" requires the formation of a separate Internet platform. Special survey forms will be developed for brands that are members of this platform. This platform is also required to be "open" to consumers.

The platform should evaluate local brands based on the following rating criteria: enterprise brand perception by consumers, brand confidence, brand satisfaction, quality and price of branded goods, consumer satisfaction with the range of branded goods, fashion and design features. 
Table 2. Rating criteria for evaluating local brands

\begin{tabular}{|c|c|c|}
\hline Factors & Identification sources & Action plan \\
\hline $\begin{array}{l}\text { Consumer perception of the brand of } \\
\text { enterprises, brand confidence, brand } \\
\text { satisfaction, quality and price of brand } \\
\text { goods, consumer satisfaction with the } \\
\text { range of brand goods, fashion and } \\
\text { design features }\end{array}$ & $\begin{array}{l}\text { 1. Based on an online survey of } \\
\text { consumers } \\
\text { 2. Opinions of consumers and } \\
\text { subscribers in the call center, } \\
\text { website, telephone numbers, } \\
\text { social media channels and } \\
\text { telegram groups of the } \\
\text { Association "Uztuqimachilik" } \\
\text { call center - 1164, telegram: } \\
\text { +998971365151) and the } \\
\text { Association "Uztuqimachilik" } \\
\text { (71 202-2244 (102), Telegram } \\
99897 \text { 733-94) }\end{array}$ & $\begin{array}{l}\text { 1.Formation of a separate } \\
\text { Internet platform by the } \\
\text { "Uztuqimachilik" } \\
\text { Association. Development of } \\
\text { special survey forms for } \\
\text { brands that are members of } \\
\text { this platform. } \\
\text { This platform is also required } \\
\text { to be "open" to consumers. } \\
\text { 2. Information are studied by } \\
\text { experts. }\end{array}$ \\
\hline Rand value of enterprises & $\begin{array}{l}\text { It is determined by the } \\
\text { Intellectual Property Agency } \\
\text { under the Ministry of Justice of } \\
\text { the Republic of Uzbekistan. }\end{array}$ & $\begin{array}{l}\text { Implemented by the initiative } \\
\text { of enterprises or the } \\
\text { "Uztuqimachilik" } \\
\text { Association }\end{array}$ \\
\hline $\begin{array}{l}\begin{array}{l}\text { Sustainability of enterprise brand } \\
\text { development }\end{array} \\
\end{array}$ & \multirow{5}{*}{$\begin{array}{l}\text { State Statistics Committee of } \\
\text { the Republic of Uzbekistan and } \\
\text { Based on the relevant } \\
\text { information of the } \\
\text { "Uztuqimachilik" Association }\end{array}$} & \multirow{5}{*}{$\begin{array}{l}\text { "Uztuqimachilik" } \\
\text { Association will create a } \\
\text { system of regular exchange of } \\
\text { information from relevant } \\
\text { government agencies in these } \\
\text { areas }\end{array}$} \\
\hline $\begin{array}{l}\text { Production, consumption (domestic, } \\
\text { foreign) and exports of the enterprise }\end{array}$ & & \\
\hline $\begin{array}{l}\text { Investment indicators of the enterprise } \\
\text { (internal, external) }\end{array}$ & & \\
\hline $\begin{array}{l}\text { Dynamics of economic growth of } \\
\text { enterprises }\end{array}$ & & \\
\hline $\begin{array}{l}\text { Human capital (domestic and } \\
\text { investment in human capital) }\end{array}$ & & \\
\hline $\begin{array}{l}\text { Factors recommended by the } \\
\text { international consulting company } \\
\text { Brand Finance and Interbrand: brand } \\
\text { recognition, popularity, marketing } \\
\text { costs, price flexibility, value added, } \\
\text { sales growth dynamics, market } \\
\text { position, market share, distribution } \\
\text { channels, brand life. }\end{array}$ & $\begin{array}{l}\text { It is determined by the } \\
\text { Intellectual Property Agency } \\
\text { under the Ministry of Justice of } \\
\text { the Republic of Uzbekistan }\end{array}$ & $\begin{array}{l}\text { 1."Uztuqimachilik" } \\
\text { Association will cooperate } \\
\text { with Brand Finance and } \\
\text { Interbrand. Membership } \\
\text { agreements will be signed } \\
\text { with these agencies. } \\
\text { 2.Informations are generated } \\
\text { by enterprises. }\end{array}$ \\
\hline
\end{tabular}

The Intellectual Property Agency under the Ministry of Justice of the Republic of Uzbekistan must ensure that the brand value of enterprises as intellectual property is reflected in the portal, which is organized once a year in accordance with the criteria for valuation.

\section{Conclusions}

This platform conducts marketing research to develop a brand strategy, study consumers, analyze the results of marketing research, and help shape effective branding for businesses. The development of a national rating system in order to include national brands in the international ranking as a global brand is a topical issue, which will provide clear methodological guidelines and strategic directions for the preparation of local brands in the global market. On this basis, it is important to develop and implement a national rating system for local brands of garment and knitwear enterprises. 
Although the strategic objectives of enterprises operating in Uzbekistan for the formation of national brands have been developed, there are no comprehensive programs aimed at enhancing their international prestige. It is difficult to form partnerships with companies that are working on programs to increase the international prestige of national brands. The development of a national rating system for brand evaluation will lead to the formation of a healthy competitive environment for local brands, protection of consumers from substandard products, the creation of an integrated system between enterprises and consumers.

\section{References}

1. Aaker D. A., Joachimsthaler E. (2000). The brand relationship spectrum: The key to the brand architecture challenge. California Management Review, 4, 8-23

2. Baker J., Grewal D., Parasuraman A. (1994). The influence of store environment on quality inferences and store image. Journal of academy of marketing science, 22 (4), 328-339

3. Vishag Badrinarayanan. The influence of brand trust and brand identification on brand evangelism // Journal of Product \& Brand Management. 2013-08-19. T. 22, вып. 5/6. C. 371-383. ISSN 1061-0421. doi:10.1108/jpbm-09-2013-0394.

4. Ikramov M.A., Ergashkhodjaeva Sh.Dj, Adylova Z.D., Ne'matov I.U. Brand management. Study guide. $\mathrm{T}$ :, Economics, 2019.p 305.

5. Adylova Z.D., Ne'matov I.U. Brand management. Study guide. T :, Economics, 2019.p 305.

6. A.R.Okboev. Using a branding strategy in managing the competitiveness of garment and knitwear enterprises. 08.00.13-Management and 08.00.11-Маркетинг. Doctor of Philosophy (PhD) dissertation in economics. TSEU. 2021.

7. Okboyev A.R. Social Network Marketing and Its Development // International Journal of Research in Management \& Business Studies (IJRMBS 2020). Vol. 7 Issue 3 July - Sept. 2020. Impact Factor: SJIFNo23 2016= 7.05. ISSN: 2348-6503 (Online) ISSN: 2348-893X (Print) pp. 38-42.

8. Okboyev A.R., O.J.Ashurkulov Directions for the introduction of an integrated quality management system to increase the competitiveness of light industry enterprises // South Asian Journal of Marketing \& Management Research (SAJMMR). Vol.10, Issue 11, November 2020 Impact Factor: SJIF№23 $2020=7.11$. pp. $107-10$.

9. Akramov T.A., Hakimov Z., Tursunov B., Oqboyev A. Evaluation of Competitiveness of Brands of Local Sewing and Knitting Enterprises. Revista Gestão Inovação e Tecnologias. Vol.11, June 2021, 11(2):716-739. DOI: 10.47059 /revistageintec.v11i2.1707. ISSN: 2237-0722.

10. Okboev A.R., Hakimov Z.A. Role of management of the brand and increasing the competitiveness of enterprises. International Scientific Conference on International Consortium on Academic Trends of Education and Science. New York. USA Aprel $6^{\text {th }}-7^{\text {th }}, 2021$.

11. Shaekina Zh.M., Tleuberdinova A.T., Usenova D.M. Assessment of the most popular country brands in the global tourism market. Tourism: Law and Economics. 2016. No. 2. S. 15-19.

\section{Copyrights}

Copyright for this article is retained by the author(s), with first publication rights granted to the journal.

This is an open-access article distributed under the terms and conditions of the Creative Commons Attribution license (http://creativecommons.org/licenses/by/4.0/). 